\title{
Zooplankton and Dead Zooplankton in Kharbeyskie Lakes of Bolshezemelskaya Tundra (Period From 2009 to 2012)
}

\author{
Olga N. Kononova**, \\ Olga P. Dubovskaya ${ }^{\mathrm{b}, \mathrm{c}}$ and Elena B. Fefilova ${ }^{\mathrm{a}}$ \\ anstitute of Biology, Komi Scientific Centre, UB RAS \\ 28 Kommunisticheskaya Str., Syktyvkar, GSP-2, 167982, Russia \\ ${ }^{b}$ Institute of Biophysics, SB RAS \\ 50 Akademgorodok, Krasnoyarsk, 660036, Russia \\ 'Siberian Federal University \\ 79 Svobodny, Krasnoyarsk, 660041, Russia
}

Received 21.06.2014, received in revised form 14.07.2014, accepted 08.08.2014

\begin{abstract}
Zooplankton composition and structure in Kharbeyskie Lakes system of Bolshezemelskaya tundra were investigated in July, August of 2009, 2010 and 2012. In total, 87 species and forms were found and more than half of them belonged to rotifers (Rotifera). Plankton fauna of the studied lakes was typical for southern tundra and presented by azonal taxa. Composition and abundance of zooplankton of Bolshoy Kharbey Lake and adjacent lakes were different and correspond to trophic conditions in ecosystems. Inter-annual dynamics of plankton communities in the lakes was determined by weather conditions. In Bolshoy Kharbey Lake four euplanktonic species of rotifers and crustaceans (Cladocera and Copepoda) dominated in terms of abundance and nine species dominated in terms of biomass. Inter-annual changes in dominant species composition were insignificant. In Bolshoy Kharbey Lake the number of dominant species were more than in the adjacent lakes. Differences in the abundance of zooplankton between littoral and prophundal zones of the main lake were not significant. Spatial distribution of species was determined by the morphology of the lakes. Depression of plankton copepods in the main and adjacent Kharbeyskie Lakes was observed in 2012 and proportion of dead individuals in crustacean communities was high. Probably it was related with mass infection of dominant species Heterocope appendiculata (Copepoda) by microparasites.
\end{abstract}

Keywords: water ecosystems of the tundra, planktonic fauna, dominated complexes of zooplankton, spatial distribution.

(C) Siberian Federal University. All rights reserved

* Corresponding author E-mail address: kon@ib.komisc.ru 


\title{
Зоо- и некрозоопланктон Харбейских озер \\ Большеземельской тундры \\ (по исследованиям 2009-2012 годов)
}

\author{
О.Н. Кононова а*, \\ О.П. Дубовская ${ }^{\tilde{\sigma}, \mathrm{s}}$, Е.Б. Фефилова \\ ${ }^{a}$ Институт биологии Коми НЦ УрО РАН \\ Россия, 167982, Сыктыєвкар, ГСП-2, Коммунистическая, 28 \\ ${ }^{6}$ Институт биофизики СО РАН \\ Россия, 660036, Красноярск, Академгородок, 50/50 \\ ${ }^{8}$ Сибирский федеральный университет \\ Россия, 660041, Красноярск, пр. Свободный, 79
}

В июле-августе 2009, 2010, 2012 г2. исследован состав и структура зоопланктона в системе Харбейских озер Большеземельской тундры. Обнаружено 87 видов и форм, из которых более половины коловратки (Rotifera). Планктонная фауна обследованных озер обычна для южных тундр и представлена азональными таксонами. Зоопланктон оз. Большой Харбей и придаточных озер различался по составу и количественным показателям, которые соответствовали различным уровням трофности экосистем. Межгодовая динамика планктонных сообществ в озерах была связана с динамикой погодных условий. Доминантный комплекс зоопланктона по численности в оз. Большой Харбей состоял из четырех, по биомассе - из девяти видов, был представлен эвпланктонными видами как коловраток, так и ракообразных (Cladocera, Cорерода) и слабо изменялся по годам. В небольших придаточных озерах число доминирующих в планктоне видов было меньшим по сравнению с оз. Большой Харбей, в глубоководных доминантный комплекс был сходен с таковым в Большом Харбее. Не было выявлено достоверных различий в количестве зоопланктона в литорали и профундали основного озера системы. Пространственное распределение видов соответствовало морфологическим особенностям водоемов. В 2012 г. в основном и придаточных Харбейских озерах наблюдалась депрессия планктонных Сорерода, проявлявшаяся в высокой доле мертвых особей этих ракообразных в численности рачкового планктона. Наблюдали поражение микропаразитами (вероятно, грибковое) доминирующего вида - Heterocope appendiculata (Copepoda).

Ключевые слова: водные экосистемы тундры, планктонная фауна, доминантные комплексы зоопланктона, пространственное распределение.

\section{Введение}

Озера Харбейской системы расположены в арктических широтах в относительном удалении от промышленных зон. В этих условиях, которые до недавнего времени считались благополучными для экосистем, существуют угрозы воздействия на природные объекты глобального потепления климата (Панин и др., 2009; Adrian et al., 2009 и др.) и трансграничных переносов загрязняющих веществ (Хубларян, Моисеенко, 2009). Зоопланктон один из важнейших и пластичных компо- 
нентов водных экосистем, играющий особую роль в процессах перемещения и аккумуляции веществ и энергии в биогеоценозах. Его разнообразие является одним из основных элементов регуляции геохимических и биохимических процессов и стабилизации биосферы (Остроумов, 2003; Tranvik et al., 2009). Moниторинг состояния планктонных сообществ в озерных экосистемах предполагает исследование их динамики, оценку фаунистического разнообразия, структуры и пространственного распределения как наиболее информативных экологических характеристик.

Целью наших исследований было выявить состав и структуру зоопланктона Харбейских озер, особенности и динамику его распределения по акватории водоемов в период 2009-2012 гг.

\section{Материал и методы}

Для этой работы использован материал, полученный из расположенных в восточной части Большеземельской тундры Харбейских озер $\quad\left(67^{\circ} 31,351^{\prime}-67^{\circ} 36,463^{\prime} \quad\right.$ с.ш., $62^{\circ} 49,747^{\prime}-$ $62^{\circ} 56,665^{\prime}$ в.д.) в 2009, 2010, 2012 гг. Полевые исследования зоопланктона озер Большой Харбей, Головка и К2 проводили 29 июля 3 августа 2009 г., 26-27 июля 2010 г. и 28 июля - 7 августа 2012 г., в озерах Л, К1, Д1 и Д2 - только в 2012 г. в тот же период.

Пробы отбирали и обрабатывали стандартными методами (Методические рекомендации..., 1984). Подробное описание обследованных водоемов и методики отбора гидробиологических проб даны в (Фефилова и др., 2014).

Зоны литорали и пелагиали разделяли по нижней границе произрастания высших водных растений: к литорали относили участки водоема от уреза воды до этой границы, к пелагиали - остальные участки. Исследования Т.А. Власовой (1976) показали, что в оз. Большой Харбей литораль распространялась от берега до глубины 2 м. В пелагиали максимальная глубина пунктов отбора проб была 12,8 м. Всего в пелагиали озера было отобрано 10 проб зоопланктона в 2009-м, 7 в 2010-м и в 6 - в 2012 гг. В литорали было обследовано в 2009 г. 14 станций, в 2010 г. - 13 и в 2012 г. -11.

В придаточных по отношению к Большому Харбею озерах не анализировали распределение зоопланктона по зонам. Наиболее крупное из этих водоемов - оз. Головка, в нем пробы отбирали на станциях глубиной до 7 м, в озерах К1 - до 9 м и в озерах Л и К 2 - до 2,5-3 м. Из озер Д1 и Д2 пробы отбирали с берега, глубину их не измеряли. Всего было собрано: в оз. Головка - в 2009 г. 4 пробы, в 2010, 2012 гг. по 6; в оз. К2 - в 2009, 2010 гг. по 2 пробы, в 2012 г. -3 ; в оз. К1 и Л по 3 пробы и в оз. Д1 и Д2 - по 1 пробе.

Температура воды в оз. Большой Харбей в 2009 г. варьировала от 14,1 до $16,9^{\circ} \mathrm{C}$, в 2010 г. - от 9,6 до $11,7^{\circ} \mathrm{C}$ и в 2012 г. - от 11,1 до $16,1^{\circ} \mathrm{C}$, в придаточных водоемах в 2012 г. - от 11,1 до $13,6^{\circ} \mathrm{C}$.

В 2012 г. параллельно отбору проб зоопланктона для изучения его структуры также отбирали пробы зоопланктона для определения количества мертвых особей в популяциях ракообразных. Всего было отобрано 9 таких проб, по одной пробе из озер Д1, Д2, Л, К2, Головка и по две пробы из озер К1 и Большой Харбей. Из озер Л, К1, К2, Головка пробы отбирали на глубоководных участках (глубина 4-9 м), из оз. Большой Харбей - на мелководной (ст. 29, глубина 0,5 м) и глубоководной (ст. 32, глубина 7 м) станциях в северной части озера. Для дифференциации живых и мертвых особей пробы подвергали окраске анилиновым голубым, методика окрашивания подробно описана О.П. Дубовской (2008). Окрашенные пробы промывали, 
фиксировали 10\%-ным формалином и хранили в прохладном месте до обработки. Обработку проводили стандартным счетным методом, отдельно подсчитывая окрашенных - умерших в водоеме до отбора пробы, и неокрашенных - бывших живыми особей в водоеме. Следует отметить, что, многократно применяя данную методику окрашивания на разных водоемах, только на Харбейских озерах мы столкнулись с трудностями при отмывании пробы от красителя. Промывку пробы осложняли колонии синезеленых водорослей (Gloeotrichia echinulata (J.S. Smith)). Эти крупные шарообразные колонии адсорбировали частицы краски, плохо отмывались и только после фиксации отдавали краску в воду, подкрашивая животных, умерших в результате фиксации, а не только умерших в водоеме. Чтобы избежать завышения доли мертвых в результате такого влияния колоний синезеленых, пробы перед фиксацией промывали дважды с перерывом в 15-30 мин или один раз до и один раз после фиксации (с перерывом 10-30 мин). Такая чрезмерная промывка могла внести некоторые артефакты в оценку доли мертвых по сравнению со стандартной методикой по (Дубовская, 2008). По результатам обработки окрашенных проб подсчитывали долю мертвых как процент мертвых от общей численности живых и мертвых особей в пробе для каждого массового вида ракообразных.

Встречаемость видов в зоопланктоне обследованных озер оценивали как отношение числа проб, где вид присутствовал, к общему числу проб (Песенко, 1982). Доминантные виды в сообществах выделяли по относительной численности или биомассе при нижнем уровне доминирования 5 \% (Лазарева и др., 2001). Старшевозрастных копеподитов идентифицировали до вида и учитывали вместе со взрослыми животными того же вида. Копеподитов младших возрастов определяли до отрядов (Calanoida или Cyclopoida), науплиусов не идентифицировали. Названия таксонов приведены в соответствии с принятыми в работе (Определитель зоопланктона..., 2010).

Видовое богатство оценивали по числу обнаруженных видов, видовое разнообразие - по индексу Шеннона-Уивера $\left(H_{N}\right.$, бит/экз и $H_{B}$, бит/г). Уровень доминирования определяли с помощью индекса доминирования Симпсона (D). Для выявления фаунистического сходства использовали коэффициент Чекановского-Съеренсена (Песенко, 1982).

Достоверность различий средних численности и биомассы зоопланктона между выборками проб определяли критерием Колмогорова-Смирнова (Лакин, 1990), который рассчитывали с использованием Statistica 6.0 для Windows.

\section{Результаты}

Видовое разнообразие

и количественное развитие зоопланктона

Харбейских озер

В зоопланктоне озер Харбейской системы было обнаружено 76 видов (табл. 1). Десять таксонов в связи с их редкостью и сложностью определения были идентифицированы до рода и один - до семейства. Большую часть видового списка составляли коловратки (Rotifera) (55\%), на ветвистоусых (Cladocera) и веслоногих (Copepoda) раков приходилось по 24 и $21 \%$ соответственно. В оз. Большой Харбей был выявлен 71 вид и формы, основу фауны составляли коловратки (54 \% числа видов). В придаточных озерах идентифицировано 70 видов и форм. Число их в разных озерах варьировало от 10 до 42 . Ведущую роль по числу видов в большинстве водоемов играли коловратки, за исключением оз. Д1, где доминировали веслоногие раки, и оз. К2, в котором преобладали ветвистоусые (табл. 1). 


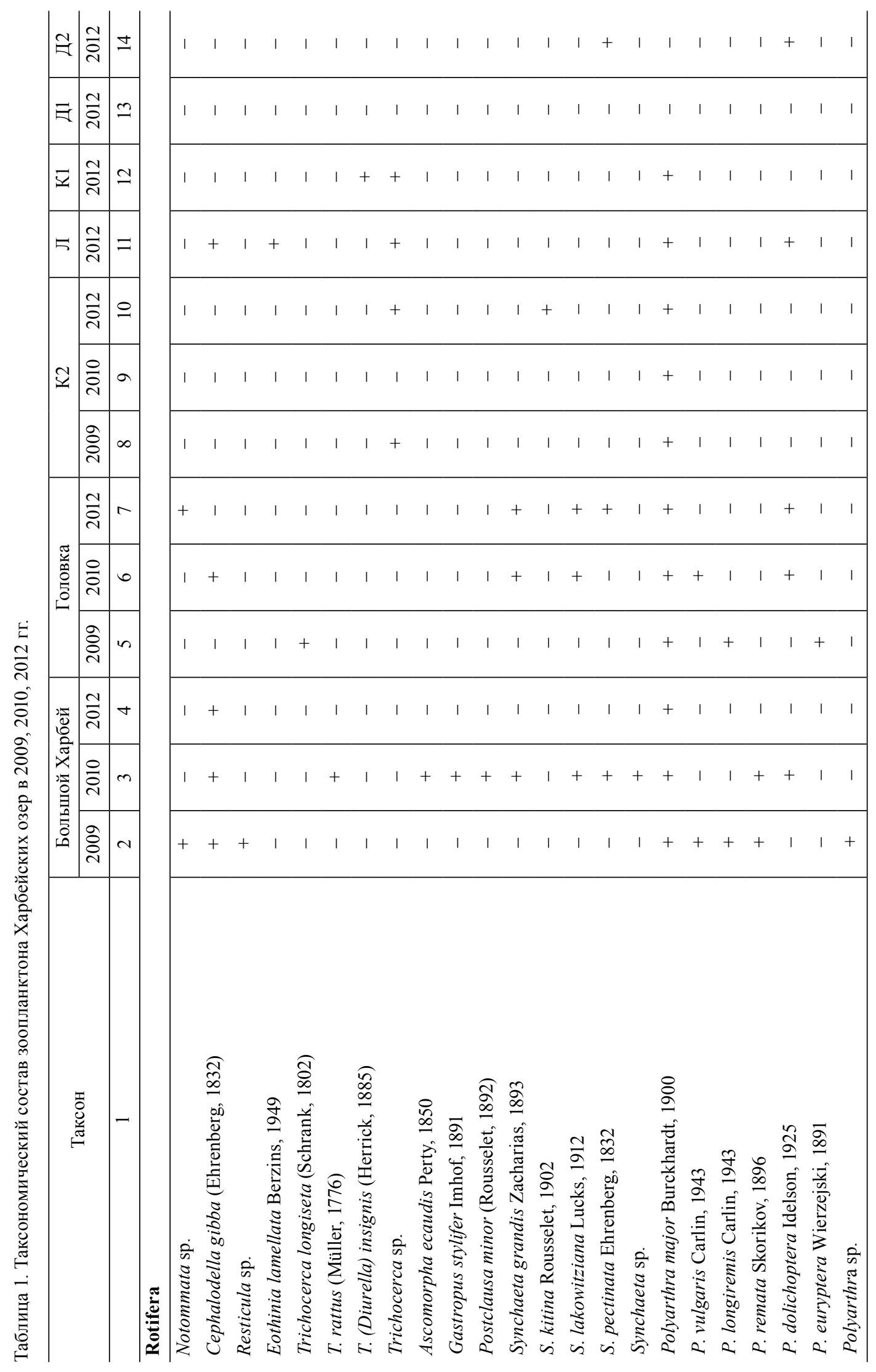




\begin{tabular}{|c|c|c|c|c|c|c|c|c|c|c|c|c|c|c|c|c|c|c|c|c|c|c|c|c|c|c|}
\hline$\Xi$ & 1 & 1 & 1 & 1 & 1 & 1 & 1 & + & 1 & 1 & 1 & 1 & 1 & 1 & 1 & + & + & 1 & 1 & + & + & 1 & 1 & + & 1 & 1 \\
\hline$\cong$ & 1 & 1 & 1 & 1 & 1 & 1 & 1 & 1 & 1 & 1 & 1 & 1 & 1 & 1 & 1 & 1 & 1 & 1 & 1 & 1 & 1 & 1 & 1 & 1 & + & 1 \\
\hline$\simeq$ & 1 & 1 & 1 & 1 & 1 & 1 & 1 & + & 1 & 1 & + & + & + & 1 & 1 & + & 1 & 1 & 1 & 1 & + & + & + & + & 1 & 1 \\
\hline$\exists$ & + & 1 & 1 & 1 & 1 & 1 & + & + & + & 1 & + & + & 1 & 1 & 1 & 1 & + & + & + & 1 & 1 & + & 1 & + & 1 & 1 \\
\hline 으 & 1 & 1 & 1 & 1 & 1 & 1 & + & 1 & 1 & 1 & 1 & + & 1 & 1 & 1 & 1 & 1 & + & 1 & 1 & + & + & 1 & + & 1 & 1 \\
\hline$a$ & + & 1 & 1 & 1 & 1 & 1 & + & 1 & 1 & 1 & 1 & 1 & 1 & 1 & 1 & 1 & 1 & 1 & 1 & 1 & 1 & + & 1 & + & 1 & 1 \\
\hline$\infty$ & + & 1 & 1 & 1 & 1 & 1 & 1 & 1 & 1 & 1 & 1 & 1 & 1 & 1 & 1 & 1 & 1 & 1 & 1 & 1 & 1 & + & 1 & + & 1 & 1 \\
\hline$r$ & 1 & 1 & 1 & 1 & 1 & 1 & + & 1 & 1 & 1 & + & 1 & + & 1 & 1 & 1 & 1 & + & 1 & 1 & 1 & + & 1 & + & 1 & 1 \\
\hline 0 & 1 & 1 & 1 & 1 & 1 & 1 & + & 1 & 1 & 1 & 1 & 1 & + & 1 & 1 & 1 & 1 & 1 & 1 & 1 & 1 & + & + & + & 1 & 1 \\
\hline in & + & 1 & 1 & 1 & 1 & 1 & + & 1 & 1 & 1 & + & 1 & + & 1 & 1 & 1 & 1 & 1 & 1 & 1 & + & + & + & + & 1 & 1 \\
\hline ナ & 1 & 1 & 1 & 1 & 1 & + & + & 1 & 1 & 1 & + & 1 & 1 & 1 & 1 & 1 & 1 & + & 1 & 1 & 1 & + & 1 & + & 1 & 1 \\
\hline$m$ & + & 1 & 1 & 1 & 1 & 1 & + & + & 1 & 1 & + & + & 1 & + & + & + & + & 1 & + & 1 & 1 & + & 1 & + & 1 & 1 \\
\hline$\sim$ & + & + & + & + & + & 1 & + & 1 & 1 & + & + & 1 & 1 & 1 & 1 & + & 1 & 1 & + & 1 & + & + & 1 & + & 1 & + \\
\hline- & 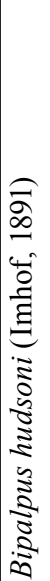 & 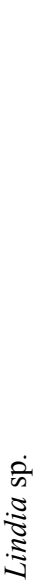 & 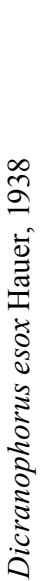 & 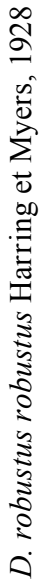 & 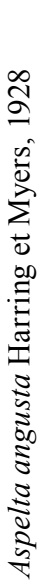 & 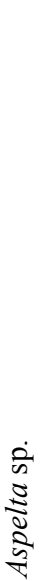 & 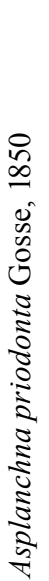 & 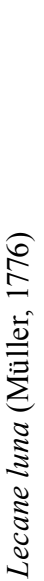 & 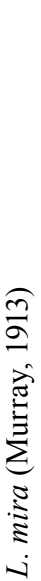 & 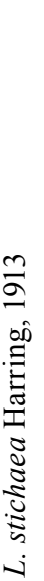 & 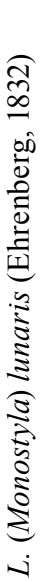 & 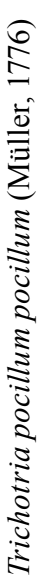 & 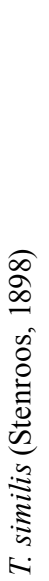 & 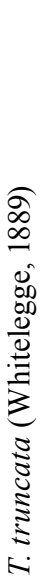 & 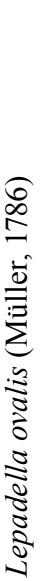 & 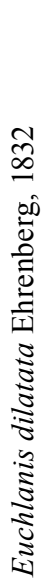 & 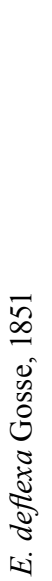 & 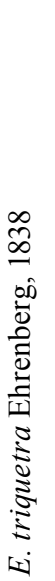 & 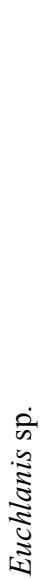 & 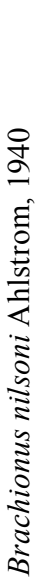 & 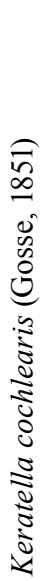 & 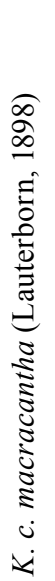 & 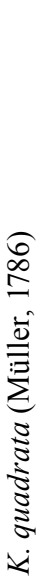 & 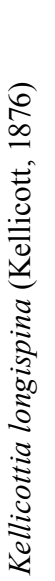 & 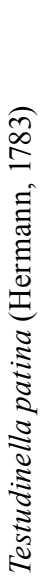 & 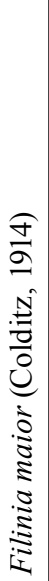 \\
\hline
\end{tabular}




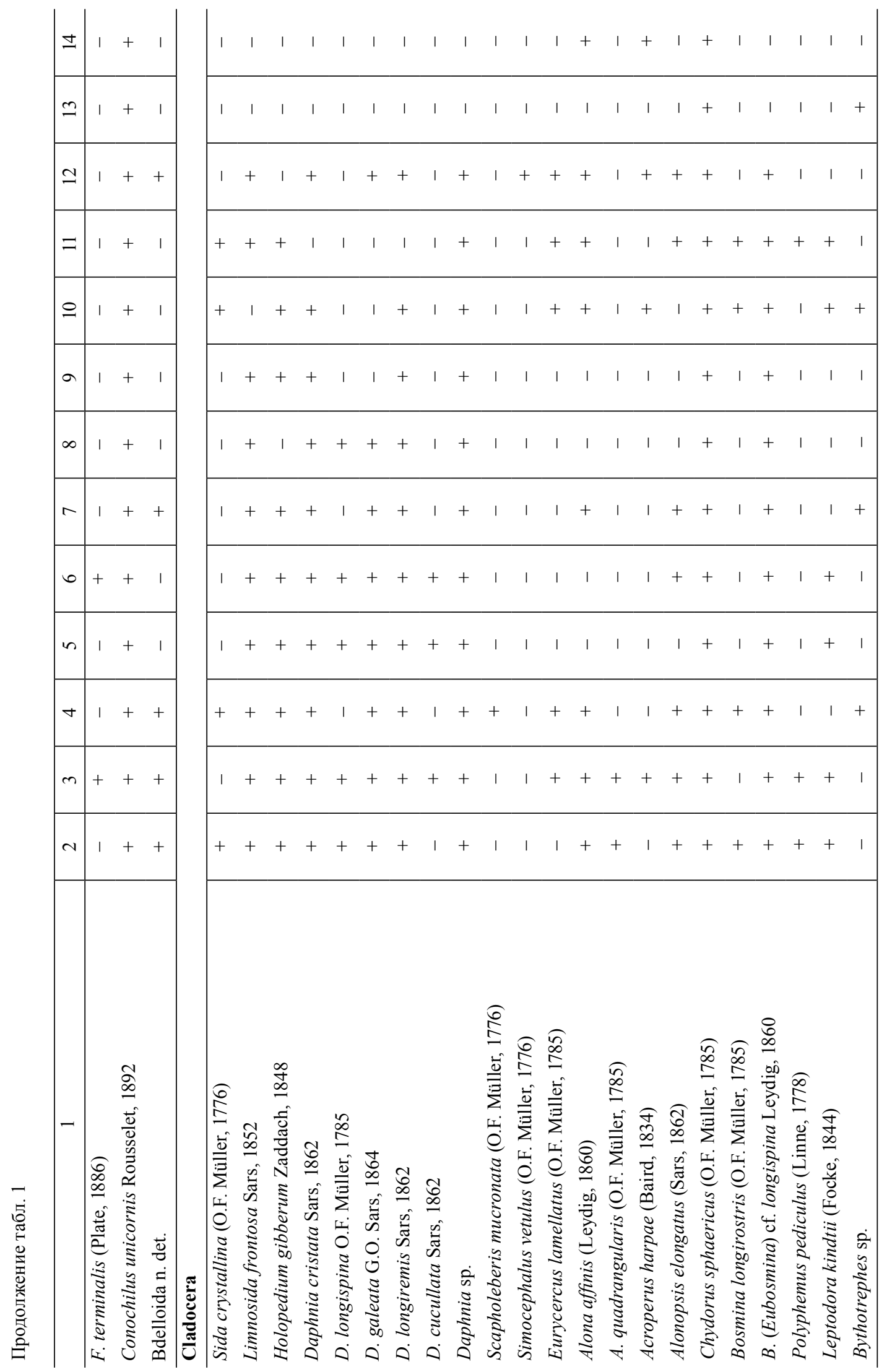




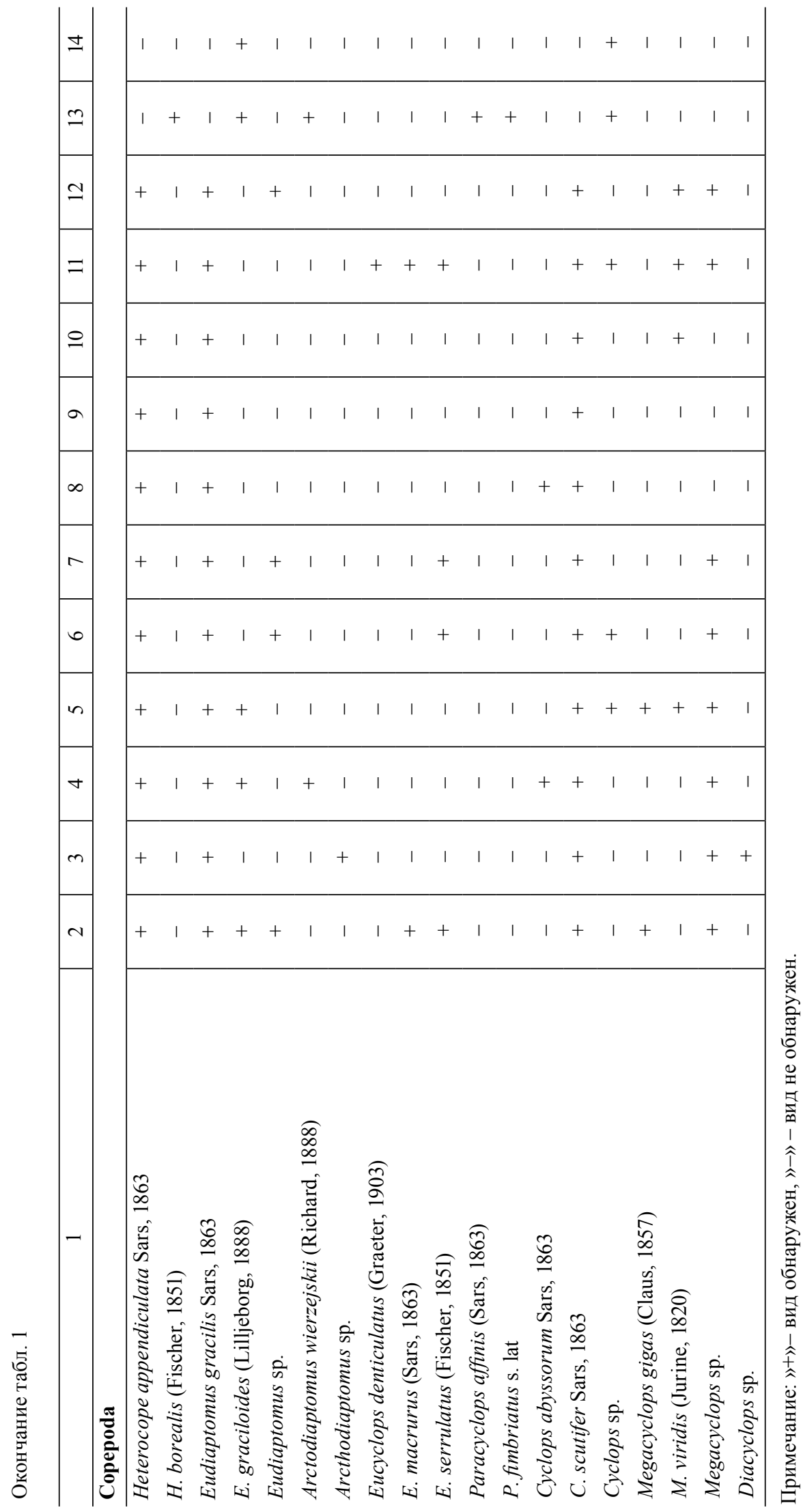


Сравнение состава фаун оз. Большой Харбей и придаточных озер показало умеренное сходство: коэффициент ЧекановскогоСъеренсена составил 0,45 . Только в планктоне оз. Большой Харбей были найдены три вида и формы низших раков и 15 - коловраток (табл. 1). Только в придаточных водоемах были встречены Polyarthra euryptera и Trichocerca longiseta - в оз. Головка, Eucyclops denticulatus, Eothinia lamellata и Lecane miraв оз. Л, Simocephalus vetulus и Trichocerca insignis - в оз. К1, Synchaeta kitina - в оз. К2, Heterocope borealis, Paracyclops affinis, P. fimbriatus и Testudinella patina - в о3. Д1 и Brachionus nilsoni - в оз. Д2. В основном перечисленные виды придонные и фитофильные. Некоторые из них (P. euryptera, B. nilsoni) являются индикаторами эвтрофирования.

Видовое разнообразие зоопланктона в обследованных водоемах варьировало в широких пределах (рис. 1). Высокие показатели индексов соответствовали уровню развития сообществ в олиготрофных и олигомезотрофных условиях (Андронникова, 1996). Наиболее низкое разнообразие зоопланктона наблюдали в озерах Д1 и Д2. Значения индекса доминирования свидетельствовали об относительно равномерном распределении численности между видами в сообществах озер, за исключением озер Д1, Д2 и К2, доминантный комплекс в которых состоял только из 2-3 видов, составлявших 73-97 \% численности зоопланктона.

Показатели количественного развития зоопланктона в Харбейских озерах представлены в табл. 2. В оз. Большой Харбей при относительно высокой численности зоопланктона биомасса была менее 1 г/м $\mathbf{M}^{3}$, что связано с преобладанием в планктонных сообществах мелких видов коловраток. В придаточных по отношению к Большому Харбею озерах К2 и Д2 коловратки также доминировали в зоопланктоне по обилию. В других озерах (Головка, Л, Д1 и К1) биомасса зоопланкто-

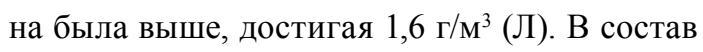
руководящего комплекса планктона входили Chydorus sphaericus, Sida crystallina и другие ветвистоусые, а также науплии веслоногих. Максимального обилия зоопланктон достигал в оз. Д2 за счет массового развития Keratella cochlearis (65\% численности зоопланктона) и Kellicottia longispina (21\%). Биомассу зоопланктона как в оз. Большой Харбей, так и в придаточных озерах формировали низшие

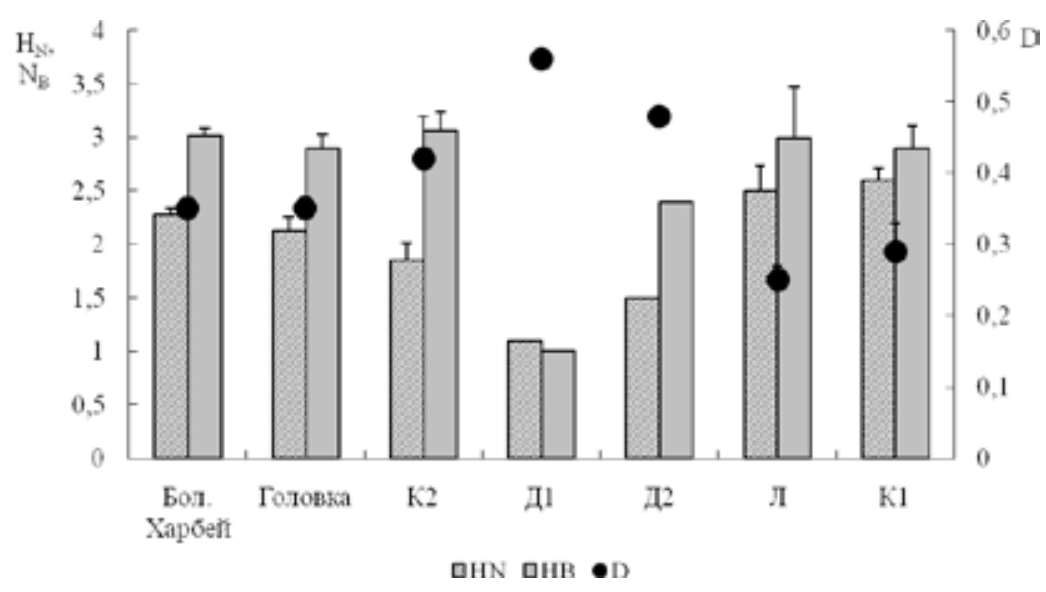

Рис. 1. Средние за период исследований индексы видового разнообразия $\left(H_{N}\right.$, бит/экз, $H_{B}$, бит/г) и доминирования (D) зоопланктона в оз. Большой Харбей и придаточных озерах 
раки, составляя от 77 до $99 \%$ общего значения (табл. 2). Исключение составило оз. Д2, в котором по биомассе преобладали коловратки (58 \% общей биомассы) (табл. 2).

Достоверных межгодовых отличий в численности и биомассе зоопланктона в оз. Большой Харбей выявлено не было, однако это равновесие складывалось за счет перераспределения численности и биомассы внутри групп зоопланктона (табл. 2). Так, в 2010 г. численность ветвистоусых раков в озере была достоверно ниже, чем в 2009 г. $(\mathrm{p}<0,001)$ и 2012 г. $(\mathrm{p}<0,01)$, а веслоногих раков - ниже, чем в 2009 г. $(\mathrm{p}<0,05)$. Относительно стабильные показатели общей биомассы (табл. 2) при достоверном снижении биомассы кладоцер в 2010 г. $(\mathrm{p}<0,001)$ достигались увеличением биомассы коловраток (относительно 2009 г. $(\mathrm{p}<0,01)$ и 2012 г. $(\mathrm{p}<0,001))$. Наиболее явно эти изменения были выражены в литорали, где снижение в 2010 г. численности $(\mathrm{p}<0,001)$ ветвистоусых раков сопровождалось вспышкой развития коловраток $(\mathrm{p}<0,05)$. Такие динамические явления в планктонных сообществах обеспечивают его устойчивость к изменениям среды обитания.

\section{Распределение}

структурообразующих видов

в зоопланктоне оз. Большой Харбей

Среди всего многообразия коловраток в оз. Большой Харбей (табл. 1) широко распространены на его акватории были только четыре вида: Asplanchna priodonta, Conochilus unicornis, $K$. longispina и $K$. cochlearis (табл. 3). Типичный представитель планктона северных озер C. unicornis был распространен и достигал высокой численности в водоеме как в пелагиали, так и в прибрежье (табл. 3, 4). Обилие конохилюса в Большом Харбее существенно варьировало как между станциями, так и по годам. Максимальной численности (344 тыс. экз./Mㄱ) вид достигал в 2010 г. в прибрежье в северной части озера, минимальной $\left(0,4\right.$ тыс. экз./ $\left.\mathbf{M}^{3}\right)$ - в этом же году на каменистом мелководье в его южной части. Несмотря на относительно небольшие размеры (320-420 мкм) (Кутикова, 1970), изза высокой численности вид входил в число доминант и по биомассе (табл. 5) в противоположность другим массовым мелким коловраткам K. longispina и $K$. cochlearis. Последние преобладали в планктоне озера лишь по численности (табл. 4). Наибольшее обилие K. longispina (104,8 тыс. экз./м³) было зарегистрировано в 2010 г. в северной части оз. Большой Харбей в заливе на выходе из протоки в оз. Головка. Keratella cochlearis больше тяготела к глубоководным участкам обследованного озера (табл. 3), но входила в состав доминантных комплексов зоопланктона по всей акватории водоема в 2009-2010 гг. (табл. 4). В 2012 г. произошло снижение численности этого вида и, хотя его отмечали на всей акватории озера, в состав доминант он не входил.

Изучение хищного зоопланктона в водоемах наряду с мирными формами имеет важное значение. По степени развития хищного планктона можно косвенно судить о состоянии экосистем. Единственный широко распространенный в озере представитель хищной фауны среди коловраток $A$. priodonta в оз. Большой Харбей достигает в длину 0,8 мм. Имеет мешковидное прозрачное тело необычной треугольной формы (рис. 2). В основном форма тела этого вида мешковидноовальная (Кутикова, 1970), но треугольную форму аспланхны находили в некоторых озеpax севера Средней Сибири (Dubovskaya et al., 2010). Вид входил в состав доминант по численности лишь однажды в 2010 г. в южной части акватории в литорали (7 \% обилия зоопланктона). Вместе с тем часто превалировал 


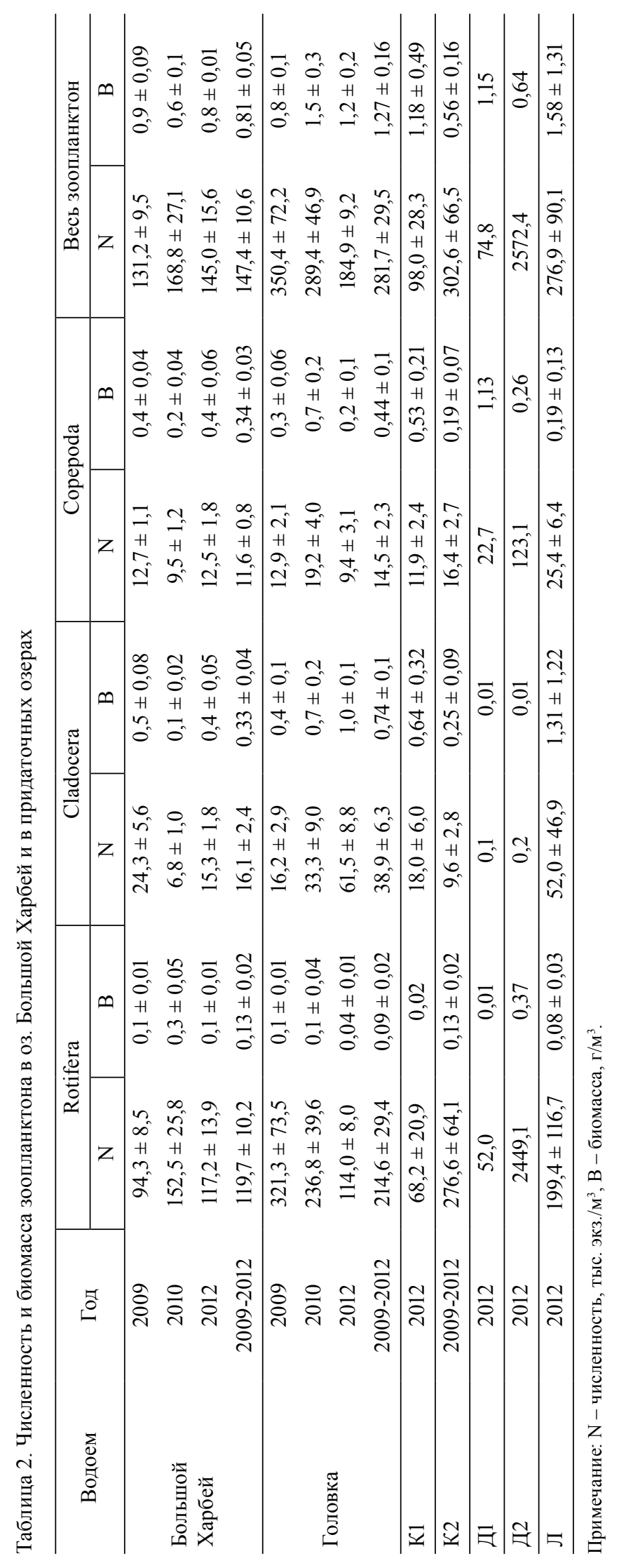


Таблица 3. Встречаемость некоторых видов в зоопланктоне в литорали и пелагиали оз. Большой Харбей

\begin{tabular}{|c|c|c|c|c|c|c|}
\hline \multirow[b]{2}{*}{ Виды } & \multicolumn{2}{|c|}{2009 г. } & \multicolumn{2}{|c|}{2010 г. } & \multicolumn{2}{|c|}{2012 г. } \\
\hline & $\begin{array}{c}\text { Lit. } \\
(\mathrm{n}=14)\end{array}$ & $\begin{array}{c}\text { Pel. } \\
(n=10)\end{array}$ & $\begin{array}{c}\text { Lit. } \\
(\mathrm{n}=13)\end{array}$ & $\begin{array}{l}\text { Pel. } \\
(n=7)\end{array}$ & $\begin{array}{c}\text { Lit. } \\
(n=11)\end{array}$ & $\begin{array}{c}\text { Pel. } \\
(n=6)\end{array}$ \\
\hline A. priodonta & +++ & +++ & +++ & +++ & ++ & +++ \\
\hline K. cochlearis & ++ & +++ & +++ & +++ & ++ & +++ \\
\hline$K$. longispina & +++ & +++ & +++ & +++ & +++ & +++ \\
\hline C. unicornis & +++ & +++ & +++ & +++ & +++ & +++ \\
\hline H. gibberum & +++ & +++ & +++ & +++ & +++ & +++ \\
\hline L. frontosa & +++ & +++ & ++ & +++ & ++ & +++ \\
\hline D. longiremis & ++ & +++ & ++ & +++ & ++ & +++ \\
\hline D. galeata & ++ & ++ & + & ++ & ++ & +++ \\
\hline D. cristata & ++ & - & ++ & + & ++ & +++ \\
\hline C. sphaericus & +++ & +++ & +++ & +++ & +++ & +++ \\
\hline B. longispina & +++ & +++ & +++ & +++ & +++ & +++ \\
\hline H. appendiculata & +++ & +++ & +++ & +++ & +++ & +++ \\
\hline E. gracilis & ++ & +++ & +++ & +++ & +++ & +++ \\
\hline E. graciloides & + & + & - & - & ++ & +++ \\
\hline C. scutifer & +++ & +++ & +++ & +++ & ++ & +++ \\
\hline
\end{tabular}

Примечание: Lit. - здесь и далее, литораль; Pel. - здесь и далее, пелагиаль; n - здесь и далее, число проб; «-«-вид не обнаружен, «+++»- вид широко распространен (>80\% станций), «++»- вид обычен (30-80 \% станций), «+»-вид редок ( $<30 \%$ станций $)$.

в водоеме по биомассе как в литорали, так и в пелагиали (табл. 5).

Наряду с вышеназванными видами коловраток в оз. Большой Харбей в разные годы высокой численности в литорали достигали Polyarthra major (в 2012 г. в южной и северной частях акватории, до 5 \% обилия зоопланктона) и Filinia terminalis (в 2010 г. в средней и южной частях, до 6 \% общего показателя).

Из 20 видов ветвистоусых раков, обнаруженных в оз. Большой Харбей, только Holopedium gibberum, Limnosida frontosa, C. sphaericus, Bosmina longispina и Daphnia longiremis были широко распространены (встречены в 80-100 \% проб) и доминировали в зоопланктоне на протяжении всего периода исследований.

Пелагический $H$. gibberum был распространен и доминировал по всей акватории озера (табл. 3,5$)$. Максимальные количественные показатели этого вида были отмечены в 2012 г. в планктоне открытой литорали южной части

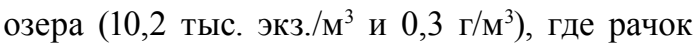
образовывал до 48 \% биомассы зоопланктона. Известно (Коровчинский, 2004), что голопедиум, типичный для северных широт вид, предпочитает глубоководные участки, реже в массе развивается в открытой литорали. В о3. Большой Харбей распределение вида было сходным с наблюдаемым в водоемах южнотаежной зоны Архангельской области (Подшивалина и др., 2012). В пелагиали рачок был малочислен, но входил в состав доминантного комплекса по биомассе в 2012 г., а в литорали являлся доминантом реже по численности и часто по биомассе (табл. 5).

Сравнительно редкий палеарктический вид L. frontosa (Коровчинский, 2004) из обследованных крупных озер Большеземельской тундры был отмечен только в озерах Хар- 
Таблица 4. Межгодовая динамика численности структурообразующих видов зоопланктона в оз. Большой Харбей

\begin{tabular}{|c|c|c|c|c|c|}
\hline \multirow{2}{*}{ Виды } & \multirow[b]{2}{*}{ Год } & \multirow{2}{*}{ Зона озера } & \multicolumn{2}{|c|}{ Численность } & \multirow{2}{*}{$\begin{array}{l}\text { Число станций, } \\
\text { на которых вид } \\
\text { доминирует, \% }\end{array}$} \\
\hline & & & Тыс. экз./ м $^{3}$ & $\%$ & \\
\hline \multirow{6}{*}{ C. unicornis } & \multirow{2}{*}{2009} & Lit. $(n=14)$ & $0,8-157,3$ & $0,5-66,0$ & 100 \\
\hline & & Pel. $(n=10)$ & $35,3-108,0$ & $43,2-60,6$ & 100 \\
\hline & \multirow{2}{*}{2010} & Lit. (n=13) & $0,4-344,0$ & $1,1-65,5$ & 85 \\
\hline & & Pel. $(n=7)$ & $14,6-52,9$ & $9,9-42,8$ & 100 \\
\hline & \multirow{2}{*}{2012} & Lit. (n=11) & $13,2-224,0$ & $36,5-83,5$ & 100 \\
\hline & & Pel. $(n=6)$ & $20,3-158,4$ & $24,3-70,6$ & 100 \\
\hline \multirow{6}{*}{$K$. longispina } & \multirow{2}{*}{2009} & Lit. (n=14) & $8,0-48,0$ & $5,3-30,5$ & 100 \\
\hline & & Pel. $(n=10)$ & $12,5-46,8$ & $15,9-31,7$ & 100 \\
\hline & \multirow{2}{*}{2010} & Lit. (n=13) & $4,0-104,8$ & $11,3-61,2$ & 100 \\
\hline & & Pel. $(n=7)$ & $3,2-56,2$ & $3,7-37,8$ & 86 \\
\hline & \multirow{2}{*}{2012} & Lit. ( $\mathrm{n}=11)$ & $5,2-32,0$ & $4,3-36,9$ & 82 \\
\hline & & Pel. $(n=6)$ & $19,4-29,3$ & $12,1-32,4$ & 100 \\
\hline \multirow{6}{*}{ K. cochlearis } & \multirow{2}{*}{2009} & Lit. (n=14) & $0-22,0$ & $0-16,8$ & 36 \\
\hline & & Pel. $(n=10)$ & $1,2-28,0$ & $1,0-12,9$ & 20 \\
\hline & \multirow{2}{*}{2010} & Lit. (n=13) & $0,4-39,2$ & $1,9-13,0$ & 85 \\
\hline & & Pel. $(n=7)$ & $14,4-50,8$ & $18,5-49,7$ & 100 \\
\hline & \multirow{2}{*}{2012} & Lit. (n=11) & $0-3,0$ & $0,3-1,9$ & - \\
\hline & & Pel. $(n=6)$ & $0,2-2,6$ & $0,3-1,7$ & - \\
\hline \multirow{6}{*}{ B. longispina } & \multirow{2}{*}{2009} & Lit. $(n=14)$ & $3,6-136,0$ & $2,9-89,6$ & 57 \\
\hline & & Pel. $(n=10)$ & $0-12,0$ & $0-5,5$ & 30 \\
\hline & \multirow{2}{*}{2010} & Lit. (n=13) & $0,1-3,2$ & $0,1-4,8$ & - \\
\hline & & Pel. $(n=7)$ & $0,4-2,0$ & $0,3-1,6$ & - \\
\hline & \multirow{2}{*}{2012} & Lit. ( $n=11)$ & $0-19,6$ & $0-18,3$ & 27 \\
\hline & & Pel. $(n=6)$ & $6,7-11,5$ & $2,3-11,6$ & 50 \\
\hline
\end{tabular}

бейской системы, в том числе в оз. Большой Харбей (табл. 3), где вид был обычен и ранее (Барановская, 1978). В отличие от голопедиума лимносида достигала высоких количественных показателей в пелагиали в северной части озера, доминируя здесь как по численности (до $5 \%$ в 2009 г.), так и по биомассе (7$10 \%$ в 2009 г. и $27 \%$ в 2010 г.). В 2009 г. вид входил в состав доминант на глубоководной станции в средней части озера, образуя 7 \% биомассы пелагического зоопланктона. В 2012 г. L. frontosa была широко распространена в озере (82 \% проб), но малочисленна.
Эврибионтный C. sphaericus имел широкое распространение в озере в течение всего периода исследований (табл. 3). Рачок доминировал по биомассе на $12-40 \%$ исследованных станций как в литорали, так и на глубоководных участках (табл. 5). Наибольшего обилия C. sphaericus достигал в 2012 г. в литорали северной части озера, где его численность составила 6 тыс. экз./ м $^{3}$ (13 \% численности зоопланктона), а биомасса $-0,07$ г/м³ (54 \% общей биомассы).

В 2009 и 2012 гг. практически по всей акватории оз. Большой Харбей в зоопланктоне 


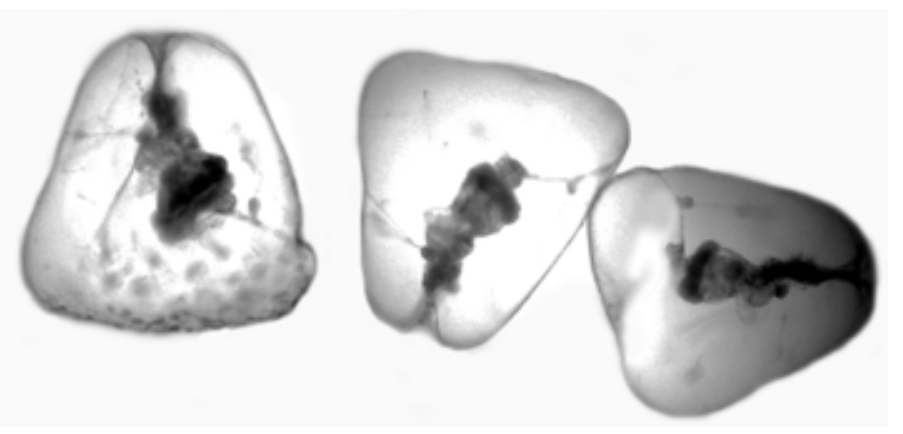

Рис. 2. Asplanhna priodonta из оз. Большой Харбей, июль 2012 г.

Таблица 5. Межгодовая динамика биомассы структурообразующих видов зоопланктона в оз. Большой Харбей

\begin{tabular}{|c|c|c|c|c|c|}
\hline \multirow[b]{2}{*}{ Виды } & \multirow[b]{2}{*}{ Год } & \multirow[b]{2}{*}{ Зона озера } & \multicolumn{2}{|c|}{ Биомасса } & \multirow{2}{*}{$\begin{array}{c}\text { Количество } \\
\text { станций, на которых } \\
\text { вид доминирует, \% }\end{array}$} \\
\hline & & & $\Gamma / M^{3}$ & $\%$ & \\
\hline 1 & 2 & 3 & 4 & 5 & 6 \\
\hline \multirow{6}{*}{ C. unicornis } & \multirow{2}{*}{2009} & Lit. $(n=14)$ & $<0,001-0,04$ & $0-9,3$ & 21 \\
\hline & & Pel. $(n=10)$ & $0,01-0,04$ & $2-4,1$ & - \\
\hline & \multirow{2}{*}{2010} & Lit. $(n=13)$ & $<0,001-0,14$ & $0,1-22$ & 62 \\
\hline & & Pel. $(n=7)$ & $0,006-0,21$ & $0,7-7$ & 29 \\
\hline & \multirow{2}{*}{2012} & Lit. $(n=11)$ & $0,005-0,09$ & $0,9-16$ & 36 \\
\hline & & Pel. $(n=6)$ & $0,008-0,06$ & $0,7-8$ & 17 \\
\hline \multirow{6}{*}{ A. priodonta } & \multirow{2}{*}{2009} & Lit. $(n=14)$ & $0-0,2$ & $0-16$ & 36 \\
\hline & & Pel. $(n=10)$ & $0-0,01$ & $0-24$ & 50 \\
\hline & \multirow{2}{*}{2010} & Lit. $(n=13)$ & $0,005-0,76$ & $2-54$ & 85 \\
\hline & & Pel. $(n=7)$ & $0-0,23$ & $0-39$ & 100 \\
\hline & \multirow{2}{*}{2012} & Lit. $(n=11)$ & $0-0,04$ & $0-17$ & 9 \\
\hline & & Pel. $(n=6)$ & $0,009-0,08$ & $1-7$ & 33 \\
\hline \multirow{6}{*}{ B. longispina } & \multirow{2}{*}{2009} & Lit. $(n=14)$ & $0,06-1,79$ & $10-91$ & 100 \\
\hline & & Pel. $(n=10)$ & $0-0,18$ & $3-17$ & 70 \\
\hline & \multirow{2}{*}{2010} & Lit. $(n=13)$ & $0,003-0,1$ & $0,8-9$ & 31 \\
\hline & & Pel. $(n=7)$ & $0,003-0,05$ & $0,6-12$ & 29 \\
\hline & \multirow{2}{*}{2012} & Lit. $(n=11)$ & $0-0,33$ & $0-53$ & 82 \\
\hline & & Pel. $(n=6)$ & $0,08-0,25$ & $8-20$ & 100 \\
\hline \multirow{6}{*}{ D. longiremis } & \multirow{2}{*}{2009} & Lit. $(n=14)$ & $0-0,64$ & $0-37$ & 50 \\
\hline & & Pel. $(n=10)$ & $0,02-0,28$ & $2-37$ & 90 \\
\hline & \multirow{2}{*}{2010} & Lit. $(n=13)$ & $0-0,06$ & $0-6$ & 8 \\
\hline & & Pel. $(n=7)$ & $0,002-0,12$ & $0,4-14$ & 29 \\
\hline & \multirow{2}{*}{2012} & Lit. $(n=11)$ & $0-0,13$ & $0-12$ & 9 \\
\hline & & Pel. $(n=6)$ & $0,1-0,31$ & $11-22$ & 100 \\
\hline \multirow{2}{*}{ H. gibberum } & \multirow{2}{*}{2009} & Lit. $(n=14)$ & $0-0,12$ & $0-16$ & 29 \\
\hline & & Pel. $(n=10)$ & $0,004-0,09$ & $0,9-10$ & 10 \\
\hline
\end{tabular}


Продолжение табл. 5

\begin{tabular}{|c|c|c|c|c|c|}
\hline 1 & 2 & 3 & 4 & 5 & 6 \\
\hline & & Lit. $(n=13)$ & $0-0,05$ & $0-14$ & 8 \\
\hline & 2010 & Pel. $(n=7)$ & $0,002-0,02$ & $0,4-3$ & - \\
\hline & & Lit. $(n=11)$ & $<0,001-0,27$ & $0,1-48$ & 18 \\
\hline & 2012 & Pel. $(n=6)$ & $0,03-0,1$ & $3-11$ & 67 \\
\hline \multirow{6}{*}{ Ch. sphaericus } & \multirow{2}{*}{2009} & Lit. $(n=14)$ & $<0,001-0,06$ & $0-8$ & 21 \\
\hline & & Pel. $(n=10)$ & $0,003-0,03$ & $0,3-2$ & - \\
\hline & \multirow{2}{*}{2010} & Lit. $(n=13)$ & $0,01-0,09$ & $2-18$ & 62 \\
\hline & & Pel. $(n=7)$ & $0,005-0,03$ & $1-6$ & 14 \\
\hline & \multirow{2}{*}{2012} & Lit. $(n=11)$ & $0,003-0,07$ & $0,3-54$ & 27 \\
\hline & & Pel. $(n=6)$ & $0,005-0,03$ & $0,2-3$ & - \\
\hline \multirow{6}{*}{ H. appendiculata } & \multirow{2}{*}{2009} & Lit. $(n=14)$ & $0,004-0,5$ & $1-52$ & 57 \\
\hline & & Pel. $(n=10)$ & $0,04-0,42$ & $6-35$ & 100 \\
\hline & \multirow{2}{*}{2010} & Lit. $(n=13)$ & $0,002-0,57$ & $1-35$ & 54 \\
\hline & & Pel. $(n=7)$ & $0,03-0,09$ & $5-21$ & 86 \\
\hline & \multirow{2}{*}{2012} & Lit. $(n=11)$ & $0,01-0,52$ & $3-80$ & 91 \\
\hline & & Pel. $(n=6)$ & $0,09-0,45$ & $10-33$ & 100 \\
\hline \multirow{6}{*}{ E. gracilis } & \multirow{2}{*}{2009} & Lit. $(n=14)$ & $0-0,12$ & $0-10$ & 14 \\
\hline & & Pel. $(n=10)$ & $0-0,14$ & $0-13$ & 20 \\
\hline & \multirow{2}{*}{2010} & Lit. $(n=13)$ & $0-0,05$ & $0-10$ & 15 \\
\hline & & Pel. $(n=7)$ & $0,004-0,04$ & $2-8$ & 43 \\
\hline & \multirow{2}{*}{2012} & Lit. $(n=11)$ & $0-0,16$ & $0-21$ & 36 \\
\hline & & Pel. $(n=6)$ & $0,03-0,08$ & $3-8$ & 67 \\
\hline \multirow{6}{*}{ C. scutifer } & \multirow{2}{*}{2009} & Lit. $(n=14)$ & $0-0,26$ & $0-31$ & 71 \\
\hline & & Pel. $(n=10)$ & $0,01-0,39$ & $3-33$ & 90 \\
\hline & \multirow{2}{*}{2010} & Lit. $(n=13)$ & $0,001-0,17$ & $0,3-18$ & 77 \\
\hline & & Pel. $(n=7)$ & $0,01-0,11$ & $3-31$ & 71 \\
\hline & \multirow{2}{*}{2012} & Lit. $(n=11)$ & $0-0,07$ & $0-7$ & 18 \\
\hline & & Pel. $(n=6)$ & $0,004-0,07$ & $0,5-5$ & 17 \\
\hline
\end{tabular}

доминировала B. longispina, достигая максимальных численности и биомассы в литорали (табл. 4, 5). В 2010 г. численность вида снижалась, однако он формировал 5-12 \% биомассы зоопланктона в северной и южной частях озера.

В оз. Большой Харбей было выявлено пять видов рода Daphnia. На протяжении трех лет исследований в водоеме были отмечены три вида: Daphnia longiremis, D. galeata и D. cristata. Daphnia cucullata была найдена только в 2010 г. в небольшом заливе на выходе из протоки, соединяющей оз. Большой Харбей с оз. Головка. Daphnia longispina встречалась в озере в 2009 и 2010 гг. как в пелагиали, так и в литорали.

Daphnia galeata была распространена по всей акватории озера и являлась обычным видом (табл. 3), преобладая на глубоководных участках (1,6-9,5 м) в восточной части озера. Daphnia cristata в 2009 г. была встречена на четырех мелководных прибрежных станциях 
в северной и средней частях озера. В 2010 г. были немногочисленные находки этого вида по всей акватории озера, как в пелагиали, так и в прибрежье. А в 2012 г. вид был распространен уже на $65 \%$ станций и входил в состав доминантных по биомассе комплексов зоопланктона в пелагиали (5-10 \% общей биомассы) и в мелководной зоне (9-12 \%). Daphnia longiremis являлась в оз. Большой Харбей наиболее широко распространенным видом дафний (табл. 3) и доминировала в зоопланктоне в течение всего периода исследований повсеместно (кроме прибрежных биотопов с глубинами менее 1 м). Интересно, что в южной части озера рачок доминировал лишь на глубоководных участках, за исключением 2010 г., когда он преобладал в планктоне (на фоне низких количественных показателей всех представителей рода дафний в этом году) как в глубоководных, так и в мелководных биотопах.

В оз. Большой Харбей обнаружено три вида хищных ветвистоусых раков: Leptodora kindtii, Polyphemus pediculus и Bythotrephes sp. Численность L. kindtii - эвпланктонного облигатного хищника - постепенно снижалась в течение периода исследований: вид был обычен (встречен в 70 \% проб) для водоема в 2009 г., стал более редким (встречаемость $20 \%$ в 2010 г. и в 2012 г. не был найден. Зато в этом году в озере появился другой хищный вид - Bythotrephes sp. Polyphemus pediculus присутствовал в 2009 и 2010 гг. в мелководном прибрежье южной части оз. Большой Харбей. Численность и биомасса этого вида были невелики: 0,02-0,06 тыс. экз./M³ и 0,007$0,02 \Gamma / \mathrm{M}^{3}$.

Среди веслоногих раков в оз. Большой Харбей были широко распространены и доминировали в зоопланктоне Heterocope appendiculata, Eudiaptomus gracilis и Cyclops scutifer (табл. 3, 5).
Один из самых крупных представителей веслоногих раков, отмеченных в озере, H. appendiculata, был распределен по его территории относительно равномерно (табл. 3) и входил в состав доминант по биомассе в разные годы на 65 - 94 \% станций (табл. 5).

Обнаружено следующее распределение в оз. Большой Харбей близкородственных видов калянид - E. gracilis и E. graciloides. Eudiaptomus gracilis был распространен в озере в течение всего периода исследований и встречался в 63-95 \% проб. При относительно невысокой численности $(0,02$ 3,1 тыс. экз./ $\mathbf{M}^{3}$ ) этот вид входил в число доминант по биомассе на 23-50 \% станций как в литорали, так и в пелагиали (табл. 5). Eudiaptomus graciloides в 2009 г. встречался только на глубоководном участке $(6,4$ м) в южной части озера и в литорали северной его части. В 2010 г. этот вид обнаружен не был, а в 2012 г. рачка находили уже на $71 \%$ обследованных станций. В этом же году E. graciloides доминировал по биомассе в южной части оз. Большой Харбей на глубоководной станции (6 м) (7 \% общей биомассы зоопланктона) и в прибрежье (18\%).

Холодолюбивый C. scutifer был широко распространен в оз. Большой Харбей и доминировал в планктоне по численности в 2009 г., а по биомассе - в течение всего периода исследований (табл. 5). В 2009-2010 гг. рачок доминировал по биомассе как в литорали, так и в пелагиали. Наибольшего обилия вид достигал в 2009 г. в северной части озера, составляя до $6 \%$ численности зоопланктона. А в 2012 г. наблюдали снижение количественных характеристик вида при относительно равномерном распределении в озере (табл. 3).

В целом, доминантные комплексы зоопланктона в литорали оз. Большой Харбей составляли 4-5 видов, в пелагиали - 3-5 видов. Большинство доминирующих в озере 
видов - типичные представители холодноводного зоопланктонного комплекса. В пространственном распределении планктонных организмов наблюдали отсутствие четко выраженного разделения их сообществ на глубоководные и литоральные. Зоопланктон на мелководных участках был представлен теми же видами, что и в пелагиали. Доминирование в северной части озера эвпланктонных видов, например, таких как L. frontosa, D. longispina, D. cristata, C. scutifer, связано с большими в сравнении с южной частью глубинами. Наличие зарослей водных макрофитов в северной части оз. Большой Харбей, а также большое количество придаточных водоемов способствовали развитию в прибрежье эвритопных и фитофильных видов, например C. sphaericus, S. crystallina и ряда других. Вместе с тем преобладание мелководных участков в южной части озера способствовало развитию видов, больше характерных для небольших мелководных водоемов, например P. pediculus.

\section{Зоопланктон}

\section{придаточньх водоемов}

Из обследованных придаточных Харбейских озер Головка и К1 являлись наиболее глубокими и относительно большими по площади, поэтому мы могли предположить в них высокое сходство сообществ зоопланктона по составу и количественным показателям. Однако благодаря лучшему развитию высшей водной растительности, наличию многочисленных хорошо прогреваемых мелководных заводей в оз. Головка численность планктонных организмов в 2012 г. была в два раза выше, чем в оз. К1 $(\mathrm{p}<0,05)$ (табл. 2). В обоих водоемах по обилию превалировали в планктоне C. unicornis, $K$. longispina и C. sphaericus. Вместе с тем биомасса 30опланктона в озерах Головка и К1 была прак- тически одинакова (табл. 2), что связано с доминированием по этому показателю ракообразных. В озере К1 по биомассе преобладали H. appendiculata (13-56 \% биомассы зоопланктона), D. longiremis (до 37 \%), A. affinis (до 34 \%), B. longispina, C. sphaericus и E. gracilis. В озере Головка основу биомассы в 2012 г. составляли C. sphaericus (15-64\%), D. cristata (9-44 \%), а также D. galeata, E. gracilis и L. frontosa.

В другие годы исследований доминантный комплекс зоопланктона по численности в оз. Головка был тем же, что и в 2012 г., в то время как биомассу в водоеме в разные годы формировали: в 2009 г. - D. longiremis (до $42 \%$ ), D. galeata (до $21 \%$ ), D. cristata (до $21 \%$ ), H. appendiculata (до $21 \%$ ), B. longispina, C. unicornis и C. sphaericus, в 2010 г. B. longispina (до 78 \%), D. longiremis (до 44 \%), H. appendiculata (до $35 \%$ ), C. sphaericus (до $34 \%$ и $A$. priodonta (до $16 \%$ ). Интересно, что при наличии в оз. Головка зарослей водных макрофитов в нем не было отмечено типично фитофильных видов ветвистоусых раков (табл. 1). Как и в оз. Большой Харбей, в оз. Головка в 2012 г. были найдены рачки рода Bythotrephes и не найдена L. kindtii.

Вторая группа небольших придаточных Харбейских озер (Л, К2, Д1 и Д2) отличалась высоким своеобразием планктонных сообществ. Количественное развитие зоопланктона (табл. 2) определяли доминирующие в них виды. Ядро планктонной фауны по численности в оз. Д1 формировали C. unicornis (70 \% численности зоопланктона), в $о 3$. Д2 - K. cochlearis (65\%), K. longispina (21\%) и Polyarthra dolychoptera (6\%); в о3. К2 C. unicornis (12-82\%), K. longispina (10-56\%) и $P$. major (13-25\%); в оз. Л -K. cochlearis (до $43 \%$ ), B. longispina (до $33 \%$ ), K. longispina (до $32 \%$ ), S. crystallina (до $28 \%$ ) и P. major (до $20 \%)$. 
Основную биомассу зоопланктона в озеpe Д1 образовывали Heterocope borealis (85 \% биомассы зоопланктона) и Arctodiaptomus wierzejskii (6\%); в оз. Д2 - P. dolychoptera (22\%), K. longispina $(20 \%)$ и K. cochlearis $(8 \%)$; в оз. Л - B. longispina (6-21\%), S. crystallina (до $58 \%$ ), P. major (до $20 \%$ и віpalpus hudsoni (до $12 \%$ ). В озере К2 состав доминантов по биомассе ежегодно различался: в 2009 г. C. unicornis (до $15 \%$ ), P. major (11-17 \%) и науплии копепод, в 2010 г. - C. unicornis (9$32 \%)$, D. longiremis (12-29\%), H. gibberum (до $13 \%$ ), H. appendiculata (до $11 \%$ ), B. longispina (до $9 \%$ и) и в 2012 г. - P. major (10-23\%), D. longiremis (6-26\%), K. longispina (9-12\%), B. longispina (до $23 \%$ ), C. sphaericus (до $14 \%$ ) и D. cristata (до $11 \%$ ).

Хищный зоопланктон в придаточных по отношению к Большому Харбею озерах был малочисленен. Leptodora kindtii встречалась в оз. Л и К2, причем в последнем этот вид был обнаружен только в 2012 г. В озере Л был найден P. pediculus. А получивший в 2012 г. широкое распространение в Большом Харбее Bythotrephes sp. был выявлен также в озерах Д1 и К2.

Меньшее количество доминирующих видов в небольших придаточных озерах относительно оз. Большой Харбей связано с морфогидрологическими характеристиками водоемов. В более глубоководных озерах доминантный комплекс зоопланктона имел общие черты с таковым в Большом Харбее. Тем не менее в каждом озере была выявлена своеобразная группировка структурообразующих видов.

\section{Некрозоопланктон}

Харбейских озер

Результаты дифференцированного учета живых и мертвых особей ракообразных в пробах зоопланктона представлены в табл. 6 .
Доля мертвых у видов кладоцер в целом была невелика и составляла от 2 до $23 \%$, причем увеличивалась она на спаде численности популяций (например, у хидоруса в оз. К1 от 1 к 5 августа, табл. 6). А вот подъем численности видов сопровождался уменьшением доли мертвых особей (например, у дафний в Большом Харбее от ст. 29 к ст. 32). Можно предположить, что в исследованных озерах в период их изучения кладоцеры были благополучны. Напротив, у копепод, особенно диаптомид, доля мертвых особей была велика, в частности у копеподитных стадий она составляла от 31 до $100 \%$ (табл. 6). При этом численность копепод, как живых (табл. 6), так и живых вместе с мертвыми, в большинстве случаев была низкой. Во всех озерах, кроме Д1 и Д2, численность (табл. 6) и/или биомасса (табл. 2) кладоцер была выше, чем копепод. По-видимому, копеподы находились в этот период в депрессии, одной из причин которой могла быть микропаразитарная инфекция. С большей долей вероятности это можно сказать о H. appendiculata. Доли мертвых особей этого вида (табл. 6) включали экземпляры с шаровидными включениями в теле, как на фото (рис. 3). Эти включения предположительно являются спорами гриба-паразита, как, например, на рисунке В.Н. Столбуновой (Столбунова, 2006, рис. 37, стр. 100). «Пораженные» рачки были окрашены частично, возможно, при отборе пробы они были еще живы. С другой стороны, известно (Дубовская, 2008), что по мере роста в мертвом рачке живых сапрофитов - грибов и бактерий интенсивность его окраски уменьшается. Так что не исключено, что пораженные рачки были уже мертвы. Однако, руководствуясь относительной целостностью покровов этих пораженных рачков, склоняемся к оценке их статуса как «еще живые, но обреченные на гибель». 
Таблица 6. Доля в численности таксона мертвых особей, \% (над чертой) и численность, экз./м³ (под чертой) живых планктонных ракообразных в озерах Харбейской системы 30.07-7.08.2012

\begin{tabular}{|c|c|c|c|c|c|c|c|}
\hline \multirow[t]{2}{*}{ Род, вид } & \multicolumn{7}{|c|}{ Озеро } \\
\hline & Д1 & Л & $\begin{array}{c}\text { K1 } \\
1 \text { авг /5 авг }\end{array}$ & K2 & Д2 & Головка & $\begin{array}{c}\text { Большой } \\
\text { Харбей } \\
\text { ст. 29/ст.32 }\end{array}$ \\
\hline Daphnia молодь & - & - & $\frac{8,7 / 5,2}{14000 / 9209}$ & $\frac{14,0}{1089}$ & - & $\frac{12,8}{6999}$ & $\frac{22,6 / 11,8}{480 / 2233}$ \\
\hline Daphnia половозрелые & - & - & $\frac{3,6 / 2,6}{3800 / 3125}$ & $\frac{5,8}{1089}$ & - & $\frac{6,0}{3944}$ & $\frac{5,6 / 3,2}{320 / 2033}$ \\
\hline B. longispina & - & $\frac{22,5}{1380}$ & $\frac{5,9 / 10,5}{7700 / 6042}$ & $\frac{9,7}{722}$ & - & $\frac{5,6}{472}$ & $\frac{7,7 / 7,6}{240 / 4067}$ \\
\hline Ch. sphaericus & - & $\frac{12,2}{720}$ & $\frac{2,4 / 11,5}{9800 / 2251}$ & $\frac{2,6}{2078}$ & - & $\frac{4,8}{13720}$ & $\frac{5,6 / 4,8}{1700 / 666}$ \\
\hline A. elongatus & - & - & - & - & - & - & $\frac{18,5 /-}{440 /-}$ \\
\hline Eudiaptomus копеподиты & - & - & $\frac{55,5 / 30,6}{640 / 1021}$ & - & - & $\frac{87,1}{111}$ & $\frac{33,3 / 37,5}{40 / 666}$ \\
\hline —«- самцы & - & - & $\frac{20,0 / 4,6}{80 / 167}$ & - & - & - & $\frac{26,0 / 20,0}{740 / 266}$ \\
\hline — — самки & - & - & $\frac{4,8 / 3,7}{1000 / 417}$ & - & - & - & $\frac{25,0 / 31,8}{60 / 500}$ \\
\hline $\begin{array}{l}\text { H. appendiculata } \\
\text { копеподиты }\end{array}$ & - & - & $\frac{12,5 * / 20,0 *}{700 / 167}$ & - & - & - & $\frac{19,3^{* / 10,7 *}}{3100 / 833}$ \\
\hline A. wierzejskii копеподит & $\frac{37,6}{4367}$ & - & - & - & - & - & - \\
\hline —《- самцы & $\frac{23,1}{333}$ & - & - & - & - & - & - \\
\hline —《- с самки & $\frac{5,4}{1167}$ & - & - & - & - & - & - \\
\hline Diaptominae копеподиты & - & $\frac{100}{0 * *}$ & - & $\frac{92,9}{78}$ & $\frac{100}{0 * * *}$ & - & - \\
\hline Cyclopoidae копеподиты & - & $\frac{4,3}{440}$ & - & - & $\frac{33,3}{1600}$ & - & - \\
\hline
\end{tabular}

Примечание: *включены особи с шаровидными включениями внутри, частично окрашенные (фото - рис. 3); ** при

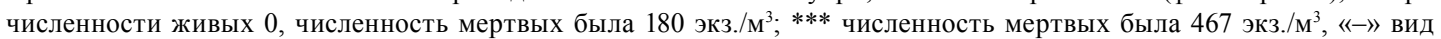
(группа) в пробе отсутствовал или его численность была низкой, вследствие чего дифференциация живых и мертвых особей не проводилась.

\section{Обсуждение}

В исследуемых озерах при относительно небольшом видовом разнообразии показатели обилия сообществ планктонных животных были достаточно высокими, что характерно для биоты тундровой зоны в целом (Чернов, 2008). Комплекс доминирующих видов в зоопланктоне Харбейских озер оказался характерным для крупных озерных экосистем Севера (Кутикова, 1978; Барановская, 1976; Зуйкова, Бочкарев, 2009 и др.). Его состав, количественное развитие и распределение по акватории обследованных водоемов были обусловлены физикоморфологическими особенностями последних. Обширные заросли высших водных растений в литорали отсутствовали. Благодаря интенсивному ветровому перемешива- 


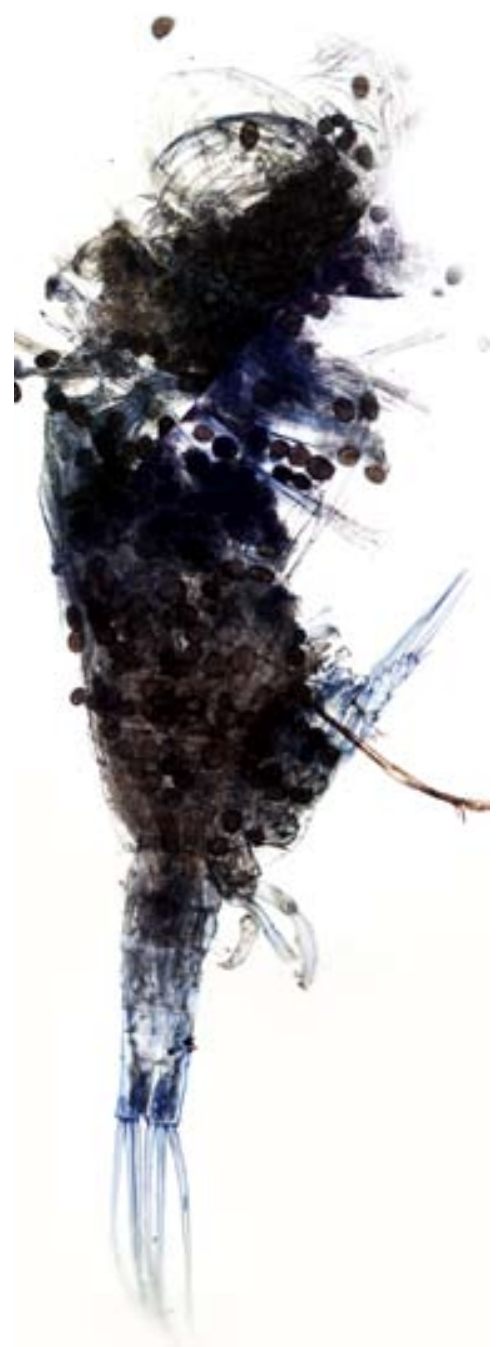

Рис. 3. Heterocope appendiculata из оз. Большой Харбей, июль 2012 г.

нию воды озер прогревались в профундали в равной степени от поверхностных слоев до дна (Батурина и др., 2012). Вместе с тем интенсивное ветровое перемешивание способствовало взмучиванию донных осадков, вследствие чего наряду с «цветением» воды в озере наблюдали небольшую прозрачность воды, что в условиях арктических широт оказывало благоприятное воздействие на развитие зоопланктона за счет поглощения ультрафиолетового света (Rautio, Korhola, 2002).
В Харбейских озерах в распределении планктонных организмов по горизонтали наблюдали отсутствие четко выраженного разделения их сообществ на пелагические и литоральные. Зоопланктон на мелководных участках был представлен теми же видами, что и в пелагиали. В ряде станций в прибрежье доминировали мелкие эвритопные виды ветвистоусых раков, например C. sphaericus. Сходные явления отмечены для некоторых других крупных водоемов, где отсутствовали обширные заросли макрофитов (Изъюрова, 1966; Бойкова, 1991; Столбунова, 1993 и др.). Вместе с тем установленные различия в количественном распределении видов зоопланктона по акватории оз. Большой Харбей могут определяться условиями, которые в глубоководной части озера имеют большую стабильность, в отличие от литорали, где более резко выражены колебания температуры, сильно проявляют себя механические факторы (прибой, волнение, перемешивание) (Киселев, 1975; Lauridsen et al., 2001; Wojtal et al., 2003 и др.). Рачки рода Daphnia, например, в оз. Большой Харбей предпочитали глубоководные участки, что позволяло им избегать воздействия ветроволнового перемешивания в прибрежной зоне. Ранее было показано (Котов, 2005), что Daphnia способны агрегироваться на глубоководных участках водоемов, где скорость течения ниже. Доминирование C. sphaericus на глубоководных участках водоемов обычно связывают с массовым развитием в этих биотопах синезеленых водорослей (Смирнов, 1971; Лазарева, 1992), что имело место в оз. Большой Харбей в 2010 г. (Патова, 2014), когда этот вид преобладал в профундали.

Доминирование в планктоне более крупных его представителей, относящихся к одному роду, как, например, в Харбейских озерах - к роду Daphnia, может быть связано с ослаблением пресса рыб-планктофагов 
(O’Brien et al., 2004). Установлено (Гиляров, $1982,1987)$, что в водоемах с высокой численностью рыб зоопланктон представлен только мелкими видами, что, однако, не приводит к снижению суммарной биомассы зоопланктона. В исследованных озерах планктоноядные рыбы - пелядь, ряпушка - являлись фоновыми представителями ихтиофауны (Сидоров, 1978). В составе питания этих рыб, а также молоди сига в августе преобладали D. longiremis, E. lamellatus, C. sphaericus и H. appendiculata (Сидоров, 1974). Интенсивность выедания зоопланктеров рыбами динамична и может варьировать из года в год, а пресс рыб по отношению к таким крупным зоопланктерам, как встречающиеся в Харбейских озерах Daphnia, Bythotrephes sp., L. kindtii, может выступать как фактор, ограничивающий не только рост их численности, но и распространение видов в водоеме (Гиляров, 1987; O'Brien et al., 2004).

Межгодовая динамика численности видов копепод рода Eudiaptomus в оз. Большой Харбей может определяться влиянием ряда факторов, в первую очередь температурой и прессом планктофагов. E. graciloides - холодолюбивый вид, способный развиваться и размножаться при низких температурах воды в подледный период (Ривьер, 2012). В теплый сезон при сильном прессе рыб понижение его численности в водоеме связано с летней диапаузой (Семенченко, Разлуцкий, 2009; Боруцкий и др., 1991; Jiménez-Melero et al, 2005; Пастернак, Михеев, 2012). Возможно, это привело к его отсутствию в планктонных пробах из оз. Большой Харбей в 2010 г. Эвритермный E. gracilis более теплолюбив, чем E. graciloides, и приступает к размножению позднее (Ривьер, 2012), при выраженном прессе рыб совершает суточные миграции (Пастернак, Михеев, 2012). В этом случае вероятность его попадания в пробы выше, и этот вид входит в состав доминантов по био- массе во все три года исследования оз. Большой Харбей.

Известно, что ветвистоусые интенсивно размножаются и дают пики численности в теплые периоды в условиях прогревания воды местообитаний (Gillooly and Dodson, 2000; Hampton et al., 2008). В связи с этим депрессия ветвистоусых (низкие численность и биомасса) в оз. Большой Харбей в 2010 г., возможно, обусловлена более низкими температурами воды в этот сезон.

Дифференцированный учет живого и мертвого зоопланктона выявил в 2012 г. высокую долю мертвых особей в популяциях калянид (и особенно диаптомид) по сравнению с кладоцерами. Возможно, эта доля завышена в связи с описанными выше трудностями применения обычных процедур окрашивания и промывки к пробам из Харбейских озер. Однако низкая численность и высокая доля мертвых характерна для популяций, находящихся в депрессии из-за не связанной с хищниками смертности, причинами которой могут быть, во-первых, неблагоприятные физические и химические факторы, вовторых, низкое качество и количество пищи, в-третьих, болезни и паразиты (Дубовская, 2009; Tang et al., 2014). В случае калянид Харбейских озер наиболее вероятной причиной нам представляется третья, если учитывать наличие среди $H$. appendiculata зараженных микропаразитами особей. В последнее время показано, что паразиты могут оказывать существенное экологическое влияние на популяции хозяев зоопланктеров, в том числе драматически снижая их численность (обзоры Tang et al., 2014; Caceres et al., 2014). В связи с обилием в пробах крупных несъедобных для зоопланктона синезеленых водорослей (Патова, 2014 и наблюдения авторов), которые к тому же считаются пищей низкого качества (Сущик, 2008; Дубовская, 2009), воз- 
можно, актуальна для калянид-фильтраторов (диаптомусов) и вторая причина их высокой смертности - качество пищи. Кладоцеры же могут более успешно усваивать несъедобный фитопланктон через микробиальную петлю (Бульон, 2002).

\section{Заключение}

В результате исследований зоопланктона озер Харбейской системы было обнаружено 87 видов и форм, характерных для водоемов северных широт. Коловратки лидировали в планктонных сообществах озер как по числу видов, так и количественно. В озере Большой Харбей численность и биомасса планктонных животных были сравнительно невелики. В высокопродуктивных придаточных озерах, напротив, при относительно низком видовом обилии наблюдали высокие количественные показатели зоопланктона. К широко распространенным и доминантным видам в о3. Большой Харбей относились эвпланктонные: H. appendiculata, E. gracilis, C. scutifer, H. gibberum, L. frontosa, B. longispina, D. longiremis, A. priodonta, C. unicornis, $K$. longispina, $K$. cochlearis и эврибионтный C. sphaericus. Их межгодовая динамика определялась температурным режимом озера и биологическими факторами, например паразитами, а также теми, которые нами не учитывались (влиянием рыб-планктофагов и количественным развитием фитопланктона). В глубоководных придаточных озерах (Головка, К1) ведущий комплекс зоопланктона формировали те же виды, что и в оз. Большой Харбей, в мелководных - наряду с ними доминировали литоральные и фитофильные виды. Состав планктонных сообществ Харбейских озер, преимущественное доминирование эврибионтных видов обусловливают высокую пластичность и динамичность их биоценозов в изменяющихся условиях среды.

Исследования были выполнены при финансовой поддержке Уральского (проекты 12С41011; 12-4-7-004-АРКТИКА) и Сибирского (проект 8) отделений РАН, гранта РФФИ (11-0500246-a).

\section{Список литературы}

1. Андроникова И.Н. (1996) Структурно-функциональная организация зоопланктона озерных экосистем разных трофических типов. СПб.: Наука, 189 с.

2. Барановская В.К. (1976) Зоопланктон Харбейских озер Большеземельской тундры. В: Винберг Г.Г., Власова Т.А. (ред.) Продуктивность озер восточной части Большеземельской тундры. Л.: Наука, с. 90-101.

3. Барановская В.К. (1978) Crustacea (Систематический список беспозвоночных из водоемов Большеземельской тундры). В: Гецен М.В. (ред.) Флора и фауна водоемов Европейского Севера. Л.: Наука, с. 174-177.

4. Батурина М.А., Лоскутова О.А., Фефилова Е.Б., Хохлова Л.Г. (2012) Зообентос озера Большой Харбей (Большеземельская тундра): современное состояние и анализ ретроспективных данных. Известия Коми научного центра УрО РАН 4 (12): 21-29.

5. Бойкова О.С. (1991) Влияние хищничества рыб на сообщество планктонных ракообразных озера Глубокого. Бюл. моск. о-ва испытателей природы. Отд. биол. 96 (2): 43-53.

6. Боруцкий Е.В., Степанова Л.А., Кос М.С. (1991) Определитель Calanoida пресных вод СССР. Л.: Наука, 504 с. 
7. Бульон В.В. (2002) Структура и функция микробиальной «петли» в планктоне озерных экосистем. Биология внутр. вод 2: 5-14.

8. Власова Т.А. (1976) Гидрологические и гидрохимические условия биологического продуцирования в озерах Харбейской системы. В: Винберг Г.Г., Власова Т.А. (ред.) Продуктивность озер восточной части Большеземельской тундры. Л.: Наука, с. 6-26.

9. Гиляров А.М. (1982) Факторы регуляции численности пресноводных ракообразных. Гидробиологический журнал 18 (5): 26-40.

10. Гиляров А.М. (1987) Динамика численности пресноводных планктонных ракообразных. М.: Наука, 190 с.

11. Дубовская О.П. (2009) Не связанная с хищниками смертность планктонных ракообразных, ее возможные причины (обзор литературы). Журн. общей биологии 70 (2): 168-192.

12. Зуйкова Е.И., Бочкарев Н.А. (2009) Характеристика пелагического зоопланктона крупных озер Тоджинской котловины (Бассейн реки Большой Енисей, Тува). Биология внутренних вод 1: 53-61.

13. Изъюрова В.К. (1966) Зоопланктон и бентические ракообразные озерно-речной системы бассейна р. Верхней Адзьвы. В: Гидалевич А.М., Чернякова М.Т. (ред.) Гидробиологическое изучение и рыбохозяйственное освоение озер крайнего севера СССР. М.: Наука, 37-50 с.

14. Киселев И.А. (1975) Планктон морей и континентальных водоемов. Т. 1. Л.: Наука, 658 с.

15. Котов А.А. (2005) Динамика распределения плотности и агрегированности Daphnia galeata Sars (Cladocera: Anomopoda) при сильном ветровом волнении. Труды гидробиологической станции на Глубоком озере им. Н.Ю. Зографа 9: 80-190.

16. Коровчинский Н.M. (2004) Ветвистоусые ракообразные отряда Ctenopoda мировой фауны (морфология, систематика, экология, зоогеография). М.: Т-во научных изданий КМК, 410 с.

17. Кутикова Л.А. (1970) Коловратки фауны СССР (Rotatoria). Подкласс Eurotatoria (отряды Ploimida, Monimotrochida, Paedotrochida). Л.: Наука, 744 c.

18. Кутикова Л.А. (1978) Коловратки В: Гецен М.В. (ред.) Флора и фауна водоемов Европейского Севера. Л.: Наука, с. 48-51.

19. Лазарева В.И. (1992) Особенности экологии ветвистоусых ракообразных в ацидных озерах юга Вологодской области. В: Смирнов Н.Н. (ред.) Современные проблемы изучения ветвистоусых ракообразных. СПб.: Гидрометеоиздат, с. 100-114.

20. Лазарева В.И., Лебедева И.М., Овчинникова Н.К. (2001) Изменение в сообществе зоопланктона Рыбинского водохранилища за 40 лет. Биология внутренних вод 4: 62-73.

21. Лакин Г.Ф. (1990) Биометрия. М.: Высшая школа, 352 с.

22. Методические рекомендации по сбору и обработке материалов при гидробиологических исследованиях на пресноводных водоемах. Зоопланктон и его продукция. (1984) Л.: Гос. НИИ озер. и реч. рыб. хоз-ва, 34 с.

23. Определитель зоопланктона и зообентоса пресных вод Европейской России. Т. 1: Зоопланктон (2010). Алексеев В.Р., Цалолихин С.Я. (ред.) М.: Товарищество науч. изданий КМК, $495 \mathrm{c}$.

24. Остроумов С.А. (2003) Гидробионты как фактор регуляции потока вещества и миграции элементов в водных экосистемах. Известия Самарского научного центра Российской академии наук 5 (2): 249-255.

$$
-325-
$$


25. Панин Г.Н., Соломонова И.В., Выручалкина Т.Ю. (2009) Климатические тенденции в средних и высоких широтах северного полушария. Водные ресурсы 36 (6): 743-756.

26. Пастернак А.Ф., Михеев В.Н. (2012) Реакция планктонных копепод Eudiaptomus spp. на пресс пелагических хищников. В: Крылов А.В. (ред.) Актуальные проблемы изучения ракообразных континентальных вод. Материалы лекций и докладов Международной школыконференции. Кострома: ООО Костромской печатный дом, с. 235-238.

27. Песенко Ю.А. (1982) Принципы и методы количественного анализа в фаунистических исследованиях. М.: Наука, 288 с.

28. Подшивалина В.Н., Шевелева Н.Г., Баянов Н.Г. (2012) Биология и экология Holopedium gibberum (Branchiopoda: Cladocera: Ctenjpoda) в Палеарктике. Гидробиологический журнал 48 (4): 22-30.

29. Ривьер И. К. (2012) Холодноводный зоопланктон озер бассейна Верхней Волги. Ижевск: Издатель Пермяков С.А., 390 с.

30. Сидоров Г.П. (1974) Рыбные ресурсы Большеземельской тундры. Л.: Наука, 164 с.

31. Сидоров Г.П. (1978) Рыбы В: Гецен М.В. (ред.) Флора и фауна водоемов Европейского Севера. Л.: Наука, с.78-83.

32. Смирнов Н.Н. (1971) Chydiridae фауны мира. Л.: Наука, 531 с.

33. Столбунова В.Н. (1993) Особенности зоопланктона мелководий верхневолжских водохранилищ и условия его существования. В: Ривьер И.К. (ред.) Зооценозы водоемов бассейна Верхней Волги в условиях антропогенного воздействия. СПб.: Гидрометеоиздат, c. 20-38.

34. Столбунова В.Н. (2006) Зоопланктон озера Плещеево. М.: Наука, 152 с.

35. Сущик Н.Н. (2008) Роль незаменимых жирных кислот в трофометаболических взаимодействиях в пресноводных экосистемах (обзор). Журн. общ. биол. 69 (4): 299-316.

36. Хубларян М.Г., Моисеенко Т.И. (2009) Качество воды. Вестник Российской академии наук 79 (5): 403-410.

37. Чернов Ю.И. (2008) Экология и биогеография. Избранные работы. М.: Товарищество научных изданий КМК, 580 c.

38. Adrian R., O’Reilly C.M., Zagarese H., Baines S.B., Hessen D.O., Keller W., Livingstone D.M., Sommaruga R., Straile D., Donk E.V., Weyhenmeyer G.A., Winder M. (2009) Lakes as sentinels of climate change. Limnol. Oceanogr. 54 (6, part 2): 2283-2297.

39. Caceres C.E., Tessier A.J., Duffy M. A., Hall S.R. (2014). Disease in freshwater zooplankton: what have we learned and where are we going? J. Plankton Res. doi:10.1093/plankt/fbt136.

40. Dubovskaya O.P., Kotov A.A., Korovchinsky N.M., Smirnov N.N., Sinev, A.Yu. (2010) Zooplankton of lakes in the spurs of the Putorana plateau and adjacent territories (North of Krasnoyarsk Krai). Contemporary Problems of Ecology 3: 401-434.

41. Gillooly J. F., Dodson S. L. (2000) Latitudinal patterns in the size distribution and seasonal dynamics of New World, freshwater cladocerans. Limnology and Oceanography 45: 2230 .

42. Hampton S.E., Izmest'eva L.R., Moore M.V., Katz S.L., Dennis B., Silov E.A. (2008) Sixty years of environmental change in the world's largest freshwater lake - Lake Baikal, Siberia. Global Change Biology 14: 1947-1958. 
43. Jiménez-Melero R., Santer B., Guerrero F. (2005) Embryonic and naupliar development of Eudiaptomus gracilis and Eudiaptomus graciloides at different temperatures: comments on individual variability. Journal of Plankton Research 27 (11): 1175-1187.

44. Karabin A., Ejsmont-Karabin J., Kornatowska R. (1997) Eutrophication processes in a shallow, macrophyte-dominated lake - factors influencing zooplankton structure and density in Lake Łuknajno (Poland). Hydrobiologia 342/343: 401-409.

45. Lauridsen T., Jeppesen E., Landkildehus F., Sondergaard M. (2001) Horizontal distribution of cladocerans in arctic Greenland lakes - impact of macrophytes and fish. Hydrobiologia 442: 107116.

46. O’Brien W.J., Barfield M., Bettez N., Hershey A.E., Hobbie J.E., Kipphut G., Kling G., Miller M.C. (2005) Long-term response and recovery to nutrient addition of a partitioned arctic lake. Freshwater Biol. 50: 731-741.

47. Rautio M., Korhola A. (2002) Effects of ultraviolet radiation and dissolved organic carbon on the survival of subarctic zooplankton. Polar. Biol. 25: 460-468.

48. Tang K.W., Gladyshev M.I, Dubovskaya O.P., Kirillin G., Grossart, H.-P. (2014) Zooplankton carcasses and non-predatory mortality in freshwater and inland sea environments Journal of Plankton Research doi:10.1093/plankt/fbu014.

49. Tranvik L.J., Downing J.A., Cotner J.B., Loiselle S.A., Striegl R.G. (2009) Lakes and reservoirs as regulators of carbon cycling and climate. Limnol. Oceanogr. 54 (6, part 2): 2298-2314.

50. Wojtal A., Frankiewicz P., Izydorczyk K., Zalewski M. (2003) Horizontal migration of zooplankton in a littoral zone of the lowland Sulejow Reservoir (Central Poland). Hydrobiologia 506-509: $339-346$. 